\title{
Type 1 Inositol 1,4,5-Trisphosphate Receptor Is Required for Induction of Long-Term Depression in Cerebellar Purkinje Neurons
}

\author{
Takafumi Inoue, ${ }^{1}$ Kunio Kato, ${ }^{2}$ Kazuhisa Kohda, ${ }^{1}$ and Katsuhiko Mikoshiba ${ }^{1,2,3}$ \\ ${ }^{1}$ Department of Molecular Neurobiology, The Institute of Medical Science, The University of Tokyo, Tokyo-108, Japan, \\ 2Mikoshiba Calciosignal Net Project, Exploratory Research for Advanced Technology (ERATO), Japan Science and \\ Technology Corporation (JST), Tokyo-153, Japan, and ${ }^{3}$ Developmental Neurobiology Laboratory, Brain Science Institute, \\ The Institute of Physical and Chemical Research (RIKEN), Wako-shi, Saitama, Japan
}

The inositol 1,4,5-trisphosphate receptor (InsP3R) is an intracellular $\mathrm{Ca}^{2+}$ channel that releases $\mathrm{Ca}^{2+}$ from internal $\mathrm{Ca}^{2+}$ stores in response to InsP3. Although InsP3R is highly expressed in various regions of the mammalian brain, the functional role of this receptor has not been clarified. We show here that cerebellar slices prepared from mice with a disrupted InsP3R type 1 gene, which is predominantly expressed in Purkinje cells, completely lack long-term depression (LTD), a model of synaptic plasticity in the cerebellum. Moreover, a specific antibody against InsP3R1, introduced into wild-type Purkinje cells through patch pipettes, blocked the induction of LTD. These data indicate that, in addition to $\mathrm{Ca}^{2+}$ influx through $\mathrm{Ca}^{2+}$ channels on the plasma membrane, $\mathrm{Ca}^{2+}$ release from InsP3R plays an essential role in the induction of LTD, suggesting a physiological importance for InsP3R in Purkinje cells.

Key words: type 1 inositol 1,4,5-trisphosphate receptor; longterm depression; cerebellar Purkinje neuron; synaptic plasticity; brain slice; patch recording; caged-InsP3
Type 1 inositol 1,4,5-trisphosphate receptor (InsP3R1) is highly expressed in cerebellar Purkinje cells (Furuichi et al., 1989, 1993). $\mathrm{Ca}^{2+}$ release by this receptor has been detected in situ (Llano et al., 1991; Vranesic et al., 1991; Khodakhah and Ogden, 1993). In the Purkinje cell, the intracellular $\mathrm{Ca}^{2+}$ concentration $\left(\left[\mathrm{Ca}^{2+}\right] \mathrm{i}\right)$ is dynamically increased by excitatory synaptic stimulation or by artificial depolarization. However, the source of the transient $\mathrm{Ca}^{2+}$ has been assigned to voltage-gated $\mathrm{Ca}^{2+}$ channels (VGCCs) that are enriched on the plasma membrane of Purkinje cells (Tank et al., 1988; Lev-Ram et al., 1992; Miyakawa et al., 1992). Despite high levels of expression, there is little direct evidence for a physiological role for InsP3R1 in Purkinje cells.

Long-term depression (LTD) at the parallel fiber (PF)-Purkinje cell synapse is a candidate mechanism for the cellular basis of motor learning and motor coordination (Ito, 1989). LTD is induced by a conjunctive stimulation of PF and climbing fiber (CF) synapses. The initial step in the induction is the temporal overlap of the large elevation of $\left[\mathrm{Ca}^{2+}\right]$ i caused by depolarization evoked by $\mathrm{CF}$ input and the activation of postsynaptic glutamate receptors at the $\mathrm{PF}$ synapse, including metabotropic glutamate receptors (mGluRs). Activation of $\mathrm{mGluR}$ results in the production of InsP3 and diacylglycerol. The former opens the InsP3R channel, and the latter activates protein kinase C (PKC) (Berridge, 1993). This signal transduction cascade is necessary for the

\footnotetext{
Received March 19, 1998; revised May 4, 1998; accepted May 6, 1998.

This work was supported by grants from the Ministry of Education, Science and Culture of Japan (T.I., K.M.). We thank D. Linden and E. Nagata for valuable information; M. Yuzaki, W. N. Ross, F. Crepel, T. Furuichi, L. G. Sayers, M. Kessler, and A. Arai for critical reading of this manuscript; H. Miyakawa for valuable discussions; T. Michikawa and A. Takahashi for preparing mAb18A10; and A. Hoshino, W. Saikawa, and M. Saito for technical assistance.

Correspondence should be addressed to Dr. Takafumi Inoue, Department of Molecular Neurobiology, The Institute of Medical Science, The University of Tokyo, 4-6-1 Shirokane-dai, Minato-ku, Tokyo-108, Japan.

Dr. Kohda's present address: Department of Developmental Neurobiology, St. Jude Children's Research Hospital, Memphis, TN 38105.

Copyright (C) 1998 Society for Neuroscience $0270-6474 / 98 / 185366-08 \$ 05.00 / 0$
}

induction of LTD, because inhibition of mGluR (Aiba et al., 1994; Conquet et al., 1994; Hartell, 1994b) or PKC (Crepel and Krupa, 1988; Hartell, 1994a; Chen et al., 1995) results in blockade of LTD. This feature is also shared by another form of LTD expressed in cultured Purkinje cells (culture-LTD) (Linden and Connor, 1991; Shigemoto et al., 1994). According to these reports, blockade of the mGluR response is caused by inhibition of PKC activation. However, it remains unclear whether InsP3R plays a role in this LTD scheme, mainly because of the lack of specific antagonists to this receptor.

LTD is blocked by the InsP3R inhibitor heparin and induced by an increase in InsP3 using caged-InsP3 in slices (Khodakhah and Armstrong, 1997) and culture-LTD (Kasono and Hirano, 1995). These experiments suggest that InsP3 is important in LTD. However, heparin may bind numerous other sites inside the cell, resulting in various nonspecific effects, including inhibition of PKC (Herbert and Maffrand, 1991). In addition, the caged-InsP3 experiments do not necessarily imply a role for InsP3R in the LTD mechanism. Thus, the necessity of $\mathrm{Ca}^{2+}$ release by InsP3Rsensitive intracellular stores to induce LTD is an unresolved question.

To examine this issue, we developed two strategies to eliminate the functional expression of InsP3R1. In one, we created a mouse strain lacking the InsP3R1 gene. In the other, we blocked the function of wild-type receptors with a specific antibody. The results of these experiments show that $\mathrm{Ca}^{2+}$ release from intracellular stores by the InsP3R1 channel is required for the induction of LTD.

Preliminary observations have been published previously (Inoue and Mikoshiba, 1997).

\section{MATERIALS AND METHODS}

Animals and preparation of slices. In experiments with mutant mice, 18- to 23-d-old InsP3R1+/+ and InsP3R1-/- animals (Matsumoto et al., 1996) were used, because InsP3R1-/- mice do not survive beyond postnatal day 23 . In the antibody experiment, 25 - to 50-d-old ddY mice 
were used, because we observed no LTD in mice younger than $25 \mathrm{~d}$ with the induction protocol of combined PF and CF stimulation (T. Inoue and K. Mikoshiba, unpublished observations). Transverse or sagittal cerebellar slices, $250 \mu \mathrm{m}$ thick, were prepared according to standard procedures using a Vibratome tissue slicer (DSK-1000, Dosaka EM, Kyoto, Japan). Transverse slices were used in LTD induction experiments because PFs are not cut in this plane, enabling more stable recording of PF-mediated EPSPs (PF-EPSP) than in sagittally cut slices. However, sagittally cut slices, in the plane of Purkinje cell dendrites, were preferred for imaging experiments. Two types of superf using saline were used: artificial CSF-A (ACSF-A) composed of (in mM): $125 \mathrm{NaCl}, 2.5 \mathrm{KCl}, 2 \mathrm{CaCl}_{2}, 1 \mathrm{MgSO}_{4}$, $1.25 \mathrm{NaH}_{2} \mathrm{PO}_{4}, 26 \mathrm{NaHCO}_{3}$, and 20 glucose; and ACSF-B composed of (in mM): $124 \mathrm{NaCl}, 5 \mathrm{KCl}, 2 \mathrm{CaCl}_{2}, 1 \mathrm{MgSO}_{4}, 1.25 \mathrm{NaH}_{2} \mathrm{PO}_{4}, 22$ $\mathrm{NaHCO}_{3}$, and 10 glucose. Both solutions were bubbled with a mixture of $95 \% \mathrm{O}_{2}$ and $5 \% \mathrm{CO}_{2}$, and kept at $32-34^{\circ} \mathrm{C}$. ACSF-A was used in the mutant mice experiments and ACSF-B was used in the antibody experiments. Bicuculline $(10 \mu \mathrm{M})$ was always added to the external solution in LTD experiments. In either external solution, LTD was successfully observed in control experiments using the same protocol (Inoue and Miloshiba, unpublished observations).

LTD experiments in mutant Purkinje cells. All experiments were performed using whole-cell patch recording under direct visualization using a fixed-stage upright microscope (BX50W I; Olympus, Tokyo, Japan) and an objective lens $(40 \times$ water immersion, NA 0.80; Olympus). Borosilicate pipettes (4-5 M 2 ) were used and were filled with a solution containing (in mM): $70 \mathrm{KCl}, 60 \mathrm{~K}$-D-gluconate, $0.5 \mathrm{EGTA}, 4 \mathrm{MgCl}_{2}, 4$ Na-ATP, 0.4 Na-GTP, 30 HEPES, pH 7.3, and 280 mOsm. ACSF-A with $10 \mu \mathrm{M}$ bicuculline was used as an external solution. Recordings were made with an AxoClamp 2A amplifier (Axon Instruments, Foster City, CA) in the current-clamp mode. For stimulation of PFs, monopolar square pulses $(200 \mu \mathrm{sec})$ were applied through a glass pipette filled with the superfusing saline. The stimulation electrode was placed on the molecular layer, 100-200 $\mu \mathrm{m}$ from the Purkinje cell. The peak amplitude of the PF-EPSP was monitored every $5 \mathrm{sec}$. Although the stimulus artifact was relatively large, it did not affect the result. Membrane potentials were held between -65 and $-68 \mathrm{mV}$ manually. To monitor changes in $R_{\mathrm{m}}$ and $R_{\mathrm{s}}$, a hyperpolarizing square pulse (ranging from -100 to $-150 \mathrm{pA}, 60 \mathrm{msec}$ duration, beginning $20 \mathrm{msec}$ before the PF stimulus) was applied through the patch pipette. Changes in $R_{\mathrm{s}}$ were compensated for with a bridge balance circuit in the amplifier. Experiments in which the EPSP amplitude was not stable during the $10 \mathrm{~min}$ period before pairing were discarded. Instability was determined if the average in any $2 \mathrm{~min}$ period during the $10 \mathrm{~min}$ period exceeded $\pm 5 \%$ range of the baseline value (baseline value was calculated as an average of the 6 min period just before the pairing). In addition, experiments in which the holding current exceeded $-650 \mathrm{pA}$ were discarded. In accepted experiments, $R_{\mathrm{m}}$ remained constant (based on the shape of the hyperpolarizing phase; see Fig. $1 A, B$, insets). During the LTD induction periods, the amplifier was switched to voltage-clamp mode (holding potential: $-60 \mathrm{mV}$ ). LTD was induced by pairing depolarization of Purkinje cells ( $200 \mathrm{msec},-60$ to $0 \mathrm{mV}$ ) with PF stimulation 240 times at $1 \mathrm{~Hz}$ (PF stimulus was delivered $50 \mathrm{msec}$ after the onset of the depolarization). This protocol was always started 15-20 min after formation of the whole-cell patch. Electrophysiological data were filtered at $2 \mathrm{kHz}$, monitored, and stored on-line at a sampling rate of $10 \mathrm{kHz}$ with an MS-DOS-based computer (PC-9801VX; NEC, Tokyo, Japan). The data were analyzed on a Macintosh computer with homemade software (TI WorkBench).

Calcium imaging in mutant cerebellar slices. Sagittally cut slices were used in ACSF-A. A patch pipette was filled with $400 \mu \mathrm{M}$ Oregon Green 488 BAPTA-2 (Molecular Probes, Eugene, OR) and $200 \mu \mathrm{M} \mathrm{1-(2-}$ nitrophenyl)ethyl (NPE)-caged inositol 1,4,5-trisphosphate (cagedInsP3; Molecular Probes) in internal solution. Fluorescence images (excitation at $470-490 \mathrm{~nm}$; emission at $515-550 \mathrm{~nm}$ ) were recorded with a cooled-CCD camera (PXL-37; Photometrics, Tucson, AZ) through a $60 \times$ water-immersion objective lens (NA 0.90; Olympus). The uncaging illumination for caged-InsP3 was provided by a pulsed laser source $(\lambda=$ $337 \mathrm{~nm}, 20 \mathrm{~Hz}, 10$ times) (VSL-337ND Nitrogen Laser; Laser Science, Newton, MA) through a quartz fiber light guide and the epi-fluorescence port of the upright microscope. The electrophysiological apparatus, the nitrogen pulse laser source, and the cooled-CCD camera were all controlled by and the data were recorded with TI WorkBench software running on a Power Macintosh 8500 (Apple Computer, Cupertino, CA). $\mathrm{Ca}^{2+}$ transients were recorded by binned-pixel images (binning $10 \times 10$ ) at 12.5 frames/sec. To obtain the fluorescence amplitude $(F)$ from each region of interest (ROI), pixel values in each region were averaged and a background level was subtracted from it. The background value was measured as an averaged value from a similar ROI in which the measured neuron was not included. The time course of the fluorescence change was plotted as a ratio, $F / F 0$. The $F$ value of each frame was divided by the value of the first frame $(F 0)$. The exposure time and neutral density filter were chosen to ensure that all pixel values were not saturated.

Ca imaging with antibodies. Experiments were performed as described in the previous section with the following differences. Transverse cerebellar slices were used in ACSF-B. mAb18A10 $(160 \mu \mathrm{g} / \mathrm{ml})$ or control rat $\mathrm{IgG}$ was added to the patch pipette solution.

Visualization of $\operatorname{Ig} G$ penetration. Sagittally cut slices were used in ACSF-B. A patch pipette was filled with $2 \mathrm{mg} / \mathrm{ml}$ FITC-conjugated goat $\mathrm{IgG}$ in the patch pipette solution. Purkinje cells were voltage-clamped at $-60 \mathrm{mV}$. Fluorescence images of FITC were taken with a cooled-CCD camera (PXL-37), with or without a confocal laser scanning unit (CSU10; Yokogawa Electric Corporation, Tokyo, Japan).

LTD experiments with antibodies. Experiments were performed as described in "LTD experiments in mutant Purkinje cells," with the following differences. ACSF-B with $10 \mu \mathrm{M}$ bicuculline was used as an external saline. During pairing periods, the CF was stimulated with an electrode in the granule cell layer in conjunction with PF stimulation. The Purkinje cell was held in current-clamp mode. Nonspecific rat IgG was purchased from Sigma (St. Louis, MO).

\section{RESULTS}

LTD was induced by pairing the depolarization of Purkinje cells with PF stimulation (240 times at $1 \mathrm{~Hz}$ ) in the InsP3R1-deficient mouse experiments. LTD induction by pairing CF and PF stimulations was not used with the mutant mice for two reasons. First, we wanted to avoid any developmental changes at presynaptic and postsynaptic sites at the CF synapse; there was a difference in paired pulse depression of CF-mediated EPSCs in the InsP3R1-/- Purkinje cell (Matsumoto et al., 1996). Second, in young wild-type Purkinje cells (younger than $25 \mathrm{~d}$ old), LTD was not induced by pairing CF and PF stimuli (4 Hz, 480 times), which is one of the typical LTD-induction protocols (Inoue and Mikoshiba, unpublished observations). The InsP3R1-deficient mice do not survive beyond postnatal day 23 (Matsumoto et al., 1996). In wild-type (InsP3R1+/+) Purkinje cells, the amplitude of the PF-EPSP was reduced to $73.8 \pm 16.5 \%$ of the control response $30 \mathrm{~min}$ after pairing (mean $\pm \mathrm{SD} ; n=9$ from eight animals) (Fig. $1 A, C$ ). The initial slope of PF-EPSPs was also decreased without any significant variation in latency, in time to peak, and in the input resistance of Purkinje cells (Fig. $1 A$, insets). In contrast, in InsP3R1-/- Purkinje cells, the amplitude of the PF response was $100.2 \pm 25.9 \%$ after the pairing $(n=11$ from seven animals) (Fig. $1 B, C$ ) and was significantly different from InsP3R $1+/+$ animals ( $p<0.05 ; t$ test) between $4-40$ min after the pairing except at the 36 and 38 min time points. Thus, LTD was not induced in InsP3R1-/- Purkinje cells.

We have shown previously that InsP3R1 is functionally knocked out in the InsP3R1-/- cerebellum using an InsP3binding assay and an InsP3-induced $\mathrm{Ca}^{2+}$ release (IICR) assay of microsome fractions from cerebellum (Matsumoto et al., 1996). To confirm these observations in living Purkinje cells, we performed the IICR assay in Purkinje cells in slices. Figure $2 C$ shows that an InsP3R1-/- Purkinje cell completely lacked IICR activity induced by release of caged-InsP3 ( $n=5$ for InsP3R1-/-; $n=4$ for InsP3R $1+/+)$. In contrast, there was no apparent difference in the time course of depolarization-induced $\mathrm{Ca}^{2+}$ transients in the soma and dendritic regions between InsP3R1 $1-$ and InsP3R1+/+ Purkinje cells (Fig. 2B). This result indicates that there was no apparent alteration in the plasma membrane $\mathrm{Ca}^{2+}$ channels and $\mathrm{Ca}^{2+}$ buffering mechanisms in the mutant mice, at least at a qualitative level. $\mathrm{Ca}^{2+}$ 


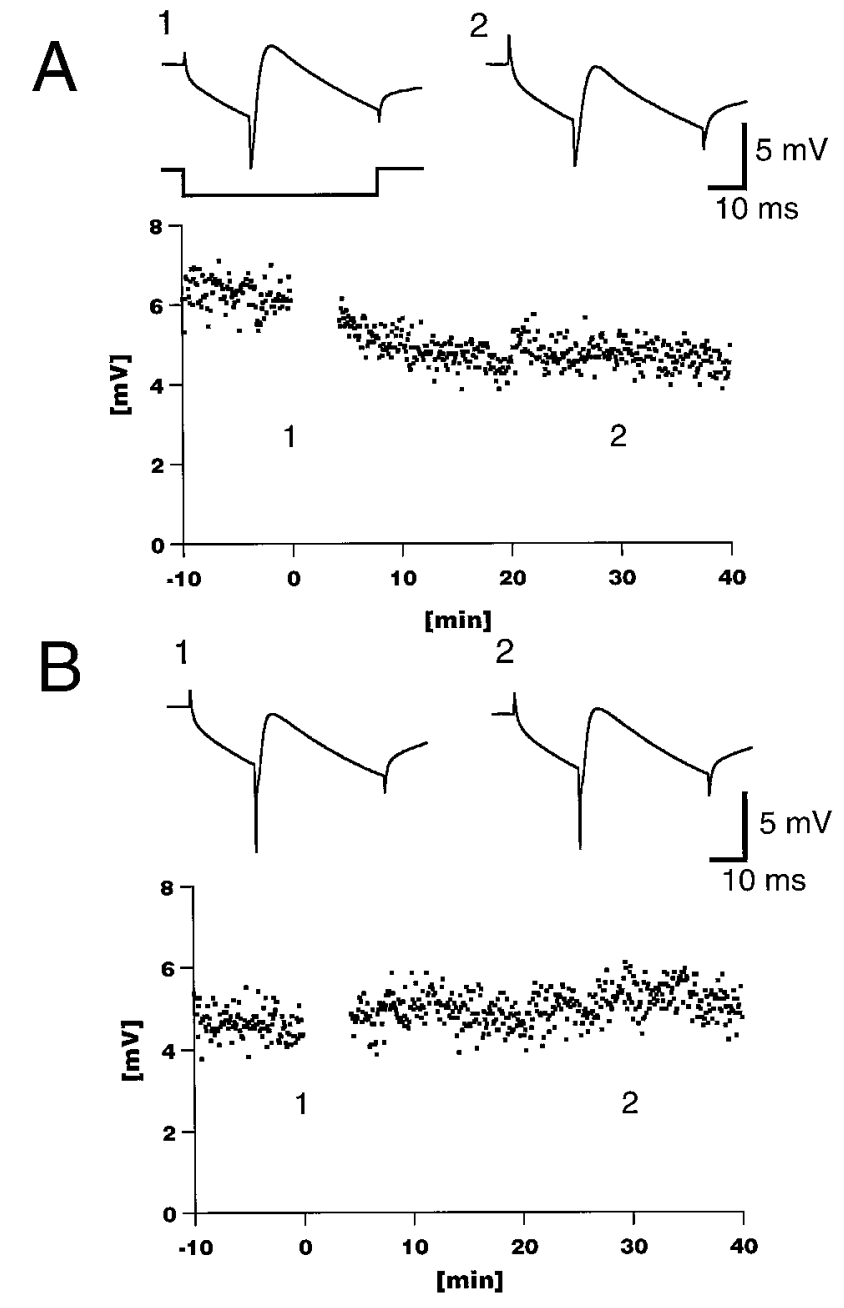

C

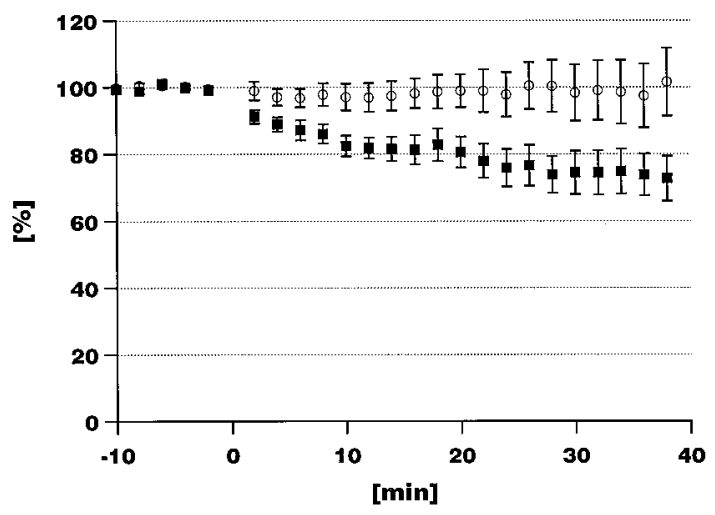

Figure 1. Loss of LTD in InsP3R1-/- Purkinje cells. A, Pairing depolarization and $\mathrm{PF}$ stimulation (1 Hz, 240 times) induced long-lasting depression of the PF-EPSP amplitude in control experiments using an InsP3R1+/+ cerebellar slice. $B$, LTD was lost in an InsP3R1-/- cerebellar slice. $A, B$, Insets show an average of 10 consecutive sweeps at time points indicated. Time course of hyperpolarizing current is also indicated at the bottom of the left inset in $A$. C, Averaged time course of normalized EPSP amplitude. LTD was not induced in InsP3R1-/- mice (O), whereas LTD was observed in control InsP3R $+/+$ mice $(\square)$. Results are presented as mean $\pm \mathrm{SEM}$.

transients evoked by depolarizations were stronger at the soma than dendritic regions in both types of Purkinje cells. Because $\mathrm{Ca}^{2+}$ transients are stronger in dendritic regions than at somata when Ca spikes occur (Tank et al., 1988; Lev-Ram et al., 1992)
(Inoue and Mikoshiba, unpublished observations), and because Ca spikes occur much less frequently in mouse Purkinje cells at ages when InsP3R $-/-$ and control mice were used (18-23 d old) (Inoue and Mikoshiba, unpublished observations), we infer that the $\mathrm{Ca}^{2+}$ transients observed in Figure $2 B$ were not caused by $\mathrm{Ca}$ spikes. The fluorescence was attenuated in the distal dendrites of InsP3R1+/+ Purkinje cells and at the soma and dendrites of the InsP3R1-/- Purkinje cells (Fig. 2C) after the UV pulses. In the proximal dendrite and soma of the InsP3R $1+/+$, this attenuation appeared to be hidden by IICR. Photo bleaching of the dye by the UV laser pulses, and not cell damage, was probably the cause of this attenuation, because caged-InsP3-induced $\mathrm{Ca}^{2+}$ release was observed repeatedly in InsP3R1+/+ Purkinje cells. In addition, depolarization-evoked $\mathrm{Ca}^{2+}$ transients (Fig. $2 B$ ) did not change after several UV pulses in both types of Purkinje cells. The attenuation by photo bleaching was not constant in different parts of a neuron, presumably because of the uneven efficacy of the UV flash. In particular, the fine dendrites in focus were effectively illuminated, but the soma was not because not all parts of the thick soma were in focus. This experiment shows that the InsP3R1-/- Purkinje cells were functionally unable to release $\mathrm{Ca}^{2+}$, although there was no obvious abnormality in the plasma membrane $\mathrm{Ca}^{2+}$ channels and the $\mathrm{Ca}^{2+}$ buffering mechanisms.

Several lines of evidence suggest that the observed lack of LTD in InsP3R1-/- Purkinje cells is a direct consequence of the gene knockout rather than an indirect developmental effect. There was no difference in the input resistance between the two types of Purkinje cells (InsP3R1+/+, $180 \pm 71 \mathrm{M} \Omega, n=17$; InsP3R1-/-, $180 \pm 57 \mathrm{M} \Omega, n=12)$. In addition, other electrophysiological characteristics of InsP3R - / - Purkinje cells, such as the complex of $\mathrm{Na}$ and $\mathrm{Ca}$ spikes, paired-pulse facilitation of PF-EPSC, and pharmacological profiles of the PF and CF synapses were indistinguishable from wild-type Purkinje cells (Matsumoto et al., 1996). There were no abnormalities in the morphology of Purkinje cells in InsP3R1-/- mice at the light microscopic level (Matsumoto et al., 1996). The expression levels of mGluR1 and mGluR5, both of which are linked to InsP3 production, were not altered in the InsP3R1-/- cerebellum (E. Nagata, personal communication). These observations strongly suggest that the lack of LTD in InsP3R1-/- Purkinje cells is a direct result of the lack of the InsP3R1 function.

To further rule out the possibility of an indirect effect of the gene knockout, we conducted a second set of experiments using the monoclonal antibody 18A10 (mAb18A10), which is a potent and selective blocker of InsP3R1 in vitro (Nakade et al., 1991), in hamster oocytes (Miyazaki et al., 1992) and in a gastric epithelial cell line (Hamada et al., 1993). We confirmed this activity of mAb18A10 in Purkinje cells in slices using caged-InsP3. The amplitude of $\mathrm{Ca}^{2+}$ transients induced by releasing caged-InsP3 declined in parallel with the diffusion of $160 \mu \mathrm{g} / \mathrm{ml} \mathrm{mAb} 18 \mathrm{~A} 10$ from the patch pipette, whereas they remained constant in a Purkinje cell loaded with $160 \mu \mathrm{g} / \mathrm{ml}$ of nonspecific rat IgG (Fig. $3 A$ ). Figure $3 B$ shows the mean normalized changes in fluorescence at the soma. Five minutes after break-in, the change in fluorescence in Purkinje cells filled with mAb18A10 was $60 \%$ smaller than that with control IgG. The difference became larger and more significant at 25 and $35 \mathrm{~min}$. Although we could detect $\mathrm{Ca}^{2+}$ transients in dendritic regions, the signals were too small to be analyzed quantitatively. Because the inhibitory potency of mAb18A10 depends on the amount of InsP3 (Nakade et al., 1991; Miyazaki et al., 1992), and because the amount of InsP3 produced during synaptic transmission is not known, the actual extent of 
A
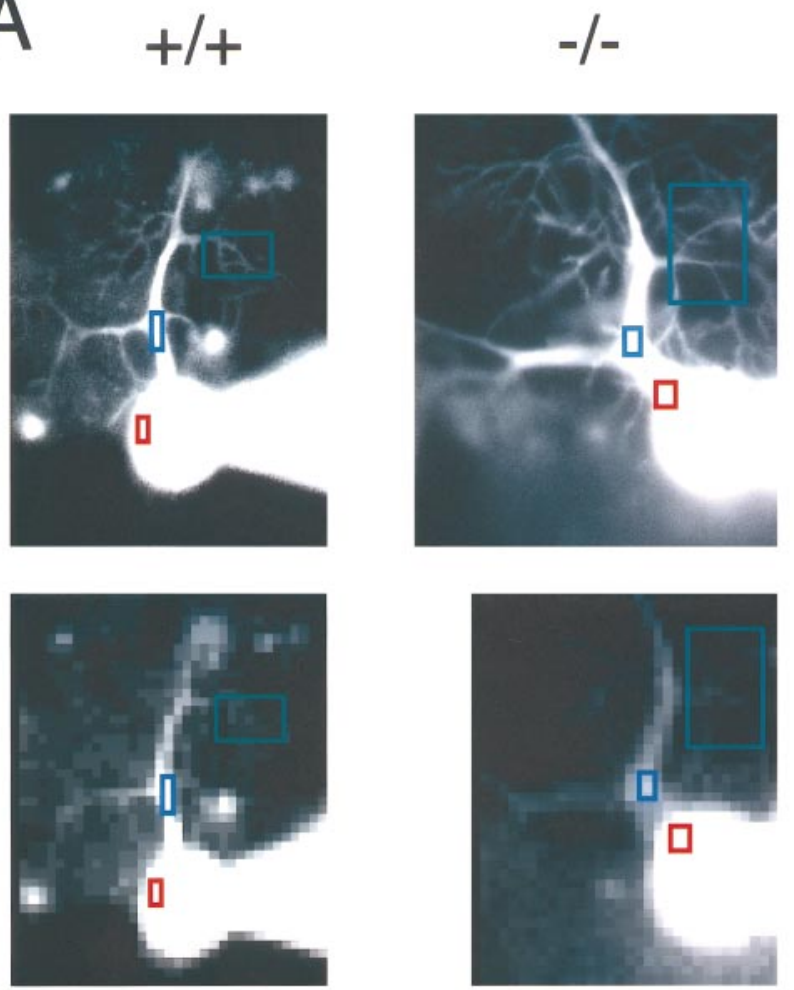

$-1-$

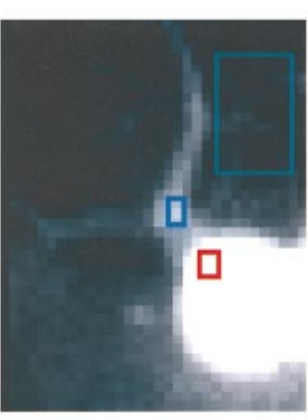

B
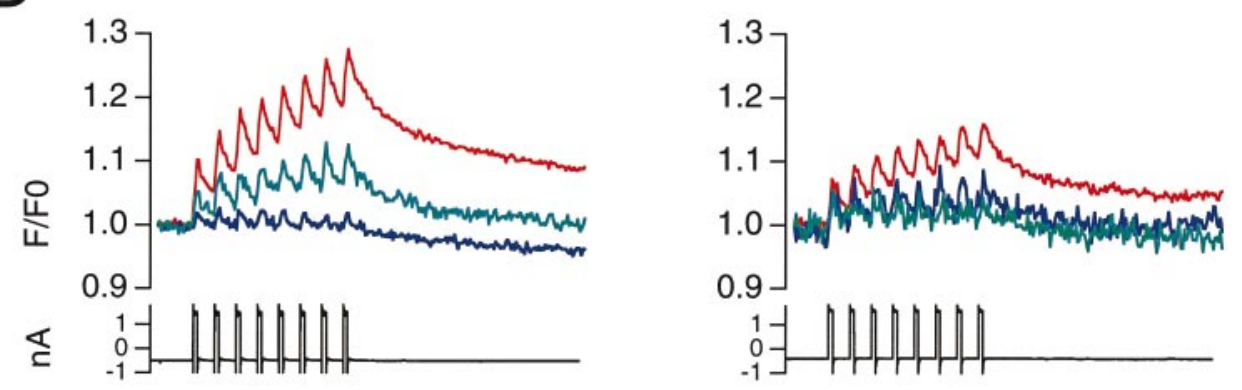

C

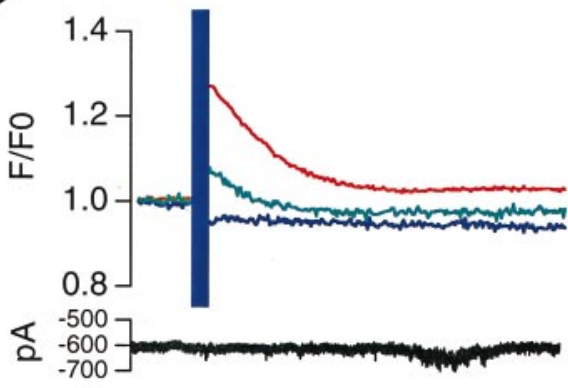

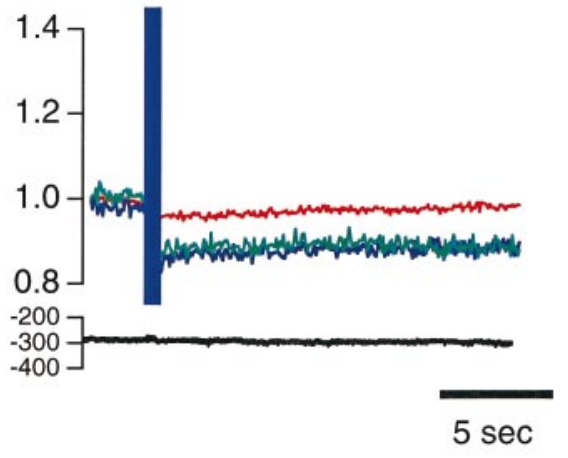

Figure 2. Calcium imaging shows normal $\mathrm{Ca}^{2+}$ transients evoked by depolarization and lack of InsP3-induced $\mathrm{Ca}^{2+}$ release in InsP3R-/- Purkinje cells. $A$, Morphology of InsP3R1+/+ and InsP3R1-/- Purkinje cells. Colored rectangles indicate regions where time courses of fluorescent changes were plotted. Top panels show fine structures of dendrites with high spatial resolution images. Bottom panels show actual images in which resolution changes in $\mathrm{Ca}^{2+}$ were measured (binning $10 \times 10$ ). Scale bar, $50 \mu \mathrm{m}$. $B, \mathrm{Ca}^{2+}$ transients were evoked by depolarization pulses. Purkinje cells from InsP3R1+/+ (left) and InsP3R1-/(right) cerebellum were voltageclamped at $-70 \mathrm{mV}$ and depolarizing pulses $(-70-0 \mathrm{mV}, 200 \mathrm{msec}, 1 \mathrm{~Hz}, 8$ times) were applied to the soma. Fluorescence intensities of indicated rectangles were averaged, corrected for background, normalized to those from the first frame (resting level), and plotted in the same color as in $A$. Current traces are also shown at the bottom of the plots. $\mathrm{Ca}^{2+}$ transients were observed at proximal (blue) and distal (green) dendritic regions as well as at the soma $(r e d) . C, \mathrm{Ca}^{2+}$ release was induced by photolysis of caged-InsP3 in the InsP3R1+/+ Purkinje cell (left) by UV laser pulses (purple band), whereas no increase in $\left[\mathrm{Ca}^{2+}\right] \mathrm{i}$ was observed in the InsP3R1-/- Purkinje cell (right). Purkinje cells were voltageclamped at $-70 \mathrm{mV}$; current traces are also shown at the bottom of the plots. Data from the same cells are shown in $A-C$. Calibration bar, $5 \mathrm{sec}$. inhibition of InsP3R1 by mAb18A10 in synaptic transmission could vary from the value obtained in this experiment.

To estimate the diffusion time of these IgGs in Purkinje cell dendrites, we investigated the migration of FITC-conjugated IgG delivered by patch pipette. Figure $4 A$ shows images obtained with a confocal unit and a CCD camera, and Figure $4 B$ shows images obtained without a confocal unit. Confocal imaging removed interference by high background fluorescence from the surface of 
A
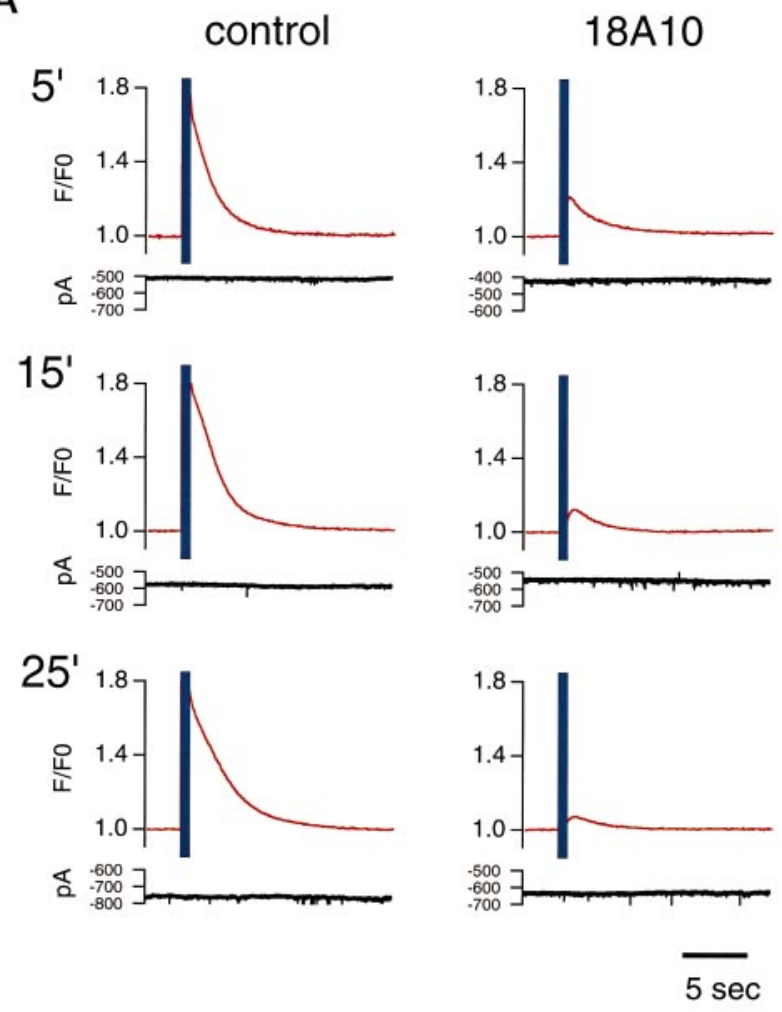

B

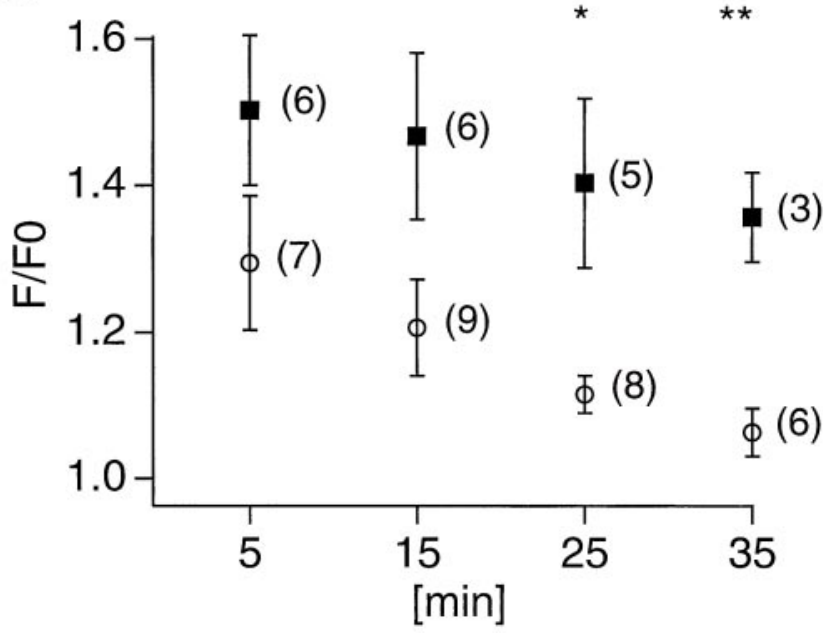

Figure 3. An InsP3R1-specific monoclonal antibody inhibited InsP3induced $\mathrm{Ca}^{2+}$ release in Purkinje cells. $A$, UV illumination (purple band) evoked InsP3-induced $\mathrm{Ca}^{2+}$ release at the soma. The amplitude of caged-InsP3-induced $\mathrm{Ca}^{2+}$ transients decreased in a mAb18A10injected Purkinje cell, whereas it did not change in a Purkinje cell loaded with control IgG. Traces were recorded at time points indicated after whole-cell patch recording was started. Fluorescence intensities were normalized to those from the first frame after subtraction of background. MAb18A10 and control IgG diffused into the cells from patch pipettes. Purkinje cells were voltage-clamped at $-70 \mathrm{mV}$; current traces are also shown at the bottom of the plots. $B$, Averaged result of caged-InsP3-induced $\mathrm{Ca}^{2+}$ release in Purkinje cells loaded with mAb18A10 (O) and control IgG (ם). Normalized changes in fluorescence at the soma were averaged and plotted against time after whole-cell recording was started. A single asterisk indicates $p<0.05$, and a double asterisk indicates $p<0.01$ ( $t$ test). Numbers beside plot marks indicate number of cells tested. the slice attributable to leakage of FITC-labeled IgG from the patch pipette while approaching the Purkinje cell, especially at early time points (Fig. 4, compare $A, B$ ). However, longer recordings were preferentially performed with a conventional CCD imaging system because of lower photobleaching of the fluorescence. The fluorescence intensity at secondary and tertiary dendrites (arrowheads) was detected as early as $3.5 \mathrm{~min}$ (Fig. $4 A$ ) and did not increase much further beyond 15 min after breaking into the cell (Fig. 4B). These results suggest that IgGs loaded from patch pipettes can reach dendritic regions within 10-20 min.

Figure 5 shows LTD experiments using mAb18A10. In this set of experiments, we used pairing of PF and CF stimuli as the LTD-inducing protocol to more closely approach in vivo conditions. In control experiments using nonspecific rat $\mathrm{IgG}$ or no $\mathrm{IgG}$, LTD was induced by pairing PF and CF stimulation 480 times at $4 \mathrm{~Hz}$ (Fig. 5A,C). The average normalized amplitude of the PF-EPSPs was $78.3 \pm 16.3 \%(n=11$ from eight animals $)$ and $76.6 \pm 18.7 \%(n=10$ from seven animals) 30 min after the pairing in the presence of $160 \mu \mathrm{g} / \mathrm{ml}$ nonspecific rat IgG and no $\mathrm{IgG}$, respectively. In contrast, when $160 \mu \mathrm{g} / \mathrm{ml}$ mAb18A10 was used, no LTD was induced by the same pairing protocol $(98.1 \pm$ $21.8 \%, n=11$ from nine animals) (Fig. $5 B, C$ ). The difference between mAb18A10 and nonspecific rat IgG was significant $(p<$ $0.05, t$ test) at all times between 4 and 40 min after the pairing except at the $10 \mathrm{~min}$ time point. The paired stimulation was started 15-20 min after break-in to ensure that the IgG reached the dendritic region of the Purkinje cell. Neither nonspecific rat IgG nor mAb18A10 altered PF-EPSPs without paired CF stimulation (Fig. 5D). Thus, 18A10 specifically blocked the induction of LTD, confirming that functional InsP3R1 is necessary for the induction of LTD.

\section{DISCUSSION}

The initial step in the induction of LTD is considered to be the temporal overlap of the large elevation of $\left[\mathrm{Ca}^{2+}\right]$ i caused by the $\mathrm{CF}$ input with activation of postsynaptic glutamate receptors at the PF synapse. Although the large $\left[\mathrm{Ca}^{2+}\right] \mathrm{i}$ increase has been thought to be mediated through VGCCs opened by the CFinduced depolarization (Tank et al., 1988; Sakurai, 1990; Crepel and Jaillard, 1991; Konnerth et al., 1992; Lev-Ram et al., 1992; Miyakawa et al., 1992), our results indicate that the increase in $\left[\mathrm{Ca}^{2+}\right] \mathrm{i}$ caused by the release of intracellular $\mathrm{Ca}^{2+}$ by InsP3R plays a specific role in the induction of LTD. Because $\mathrm{Ca}^{2+}$ influx through VGCCs occurs at the plasma membrane, and because $\mathrm{Ca}^{2+}$ is an intracellular signal with a short-acting range attributable to intracellular $\mathrm{Ca}^{2+}$ buffers (Allbritton et al., 1992; Kasai and Petersen, 1994), $\mathrm{Ca}^{2+}$ released from intracellular pools through InsP3R may reach different regions than those affected by the $\mathrm{Ca}^{2+}$ influx mediated through VGCCs. In addition to spatial differences, the two types of $\left[\mathrm{Ca}^{2+}\right]$ i regulatory mechanisms may differ temporally. Thus, InsP3R1 may mediate spatiotemporalspecific $\mathrm{Ca}^{2+}$ signals that are essential for the induction of LTD.

IICR could be modulated by the high $\left[\mathrm{Ca}^{2+}\right]$ i resulting from $\mathrm{Ca}^{2+}$ influx. The activity of InsP3R1 is sensitive to changes in $\left[\mathrm{Ca}^{2+}\right] \mathrm{i}$ in a biphasic manner (Bezprozvanny et al., 1991). The InsP3R1 channel could be activated by elevated $\left[\mathrm{Ca}^{2+}\right] \mathrm{i}$ even at the resting InsP3 concentration, which would boost $\left[\mathrm{Ca}^{2+}\right] \mathrm{i}$ elevation further. On the other hand, Khodakhah and Ogden (1995) reported that IICR was inhibited by high $\left[\mathrm{Ca}^{2+}\right] \mathrm{i}$ in the Purkinje cell, suggesting that there could be a negative interaction between $\left[\mathrm{Ca}^{2+}\right] \mathrm{i}$ and the IICR activity. The details of the $\left[\mathrm{Ca}^{2+}\right] \mathrm{i}$ dynam- 
A $1^{\prime}$

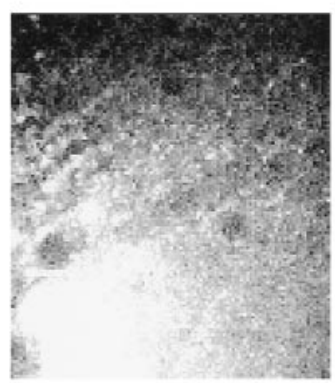

$\mathrm{B}$ $7^{\prime}$

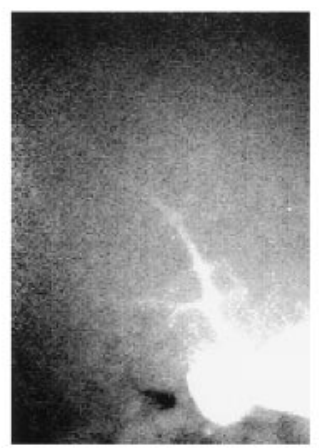

$3.5^{\prime}$

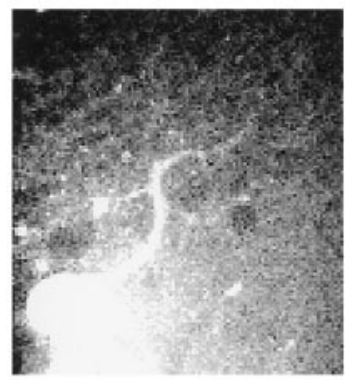

$10^{\prime}$

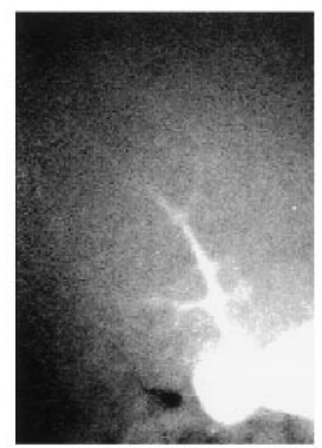

$7^{\prime}$

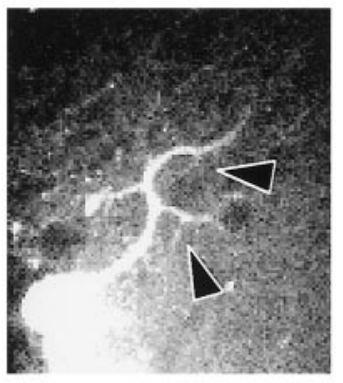

$15^{\prime}$

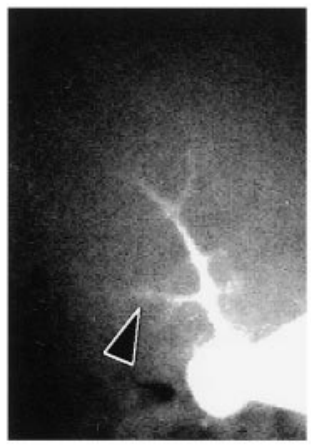

$15^{\prime}$

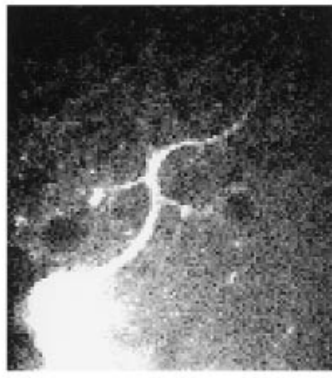

$30^{\prime}$

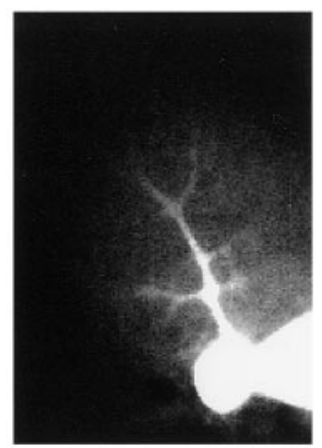

$22^{\prime}$

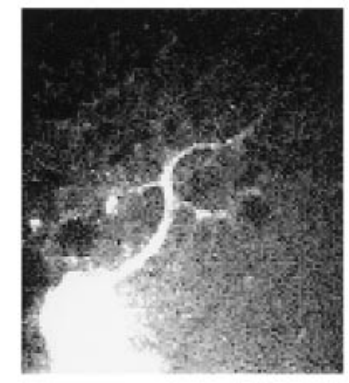

$60^{\prime}$

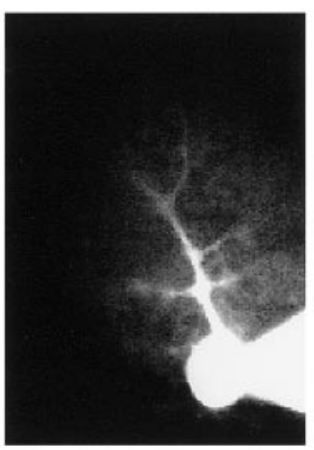

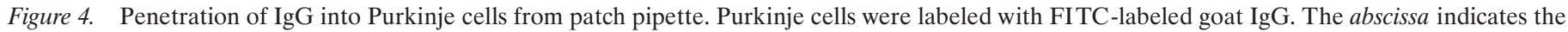

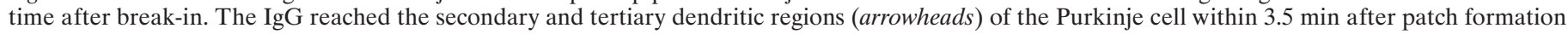

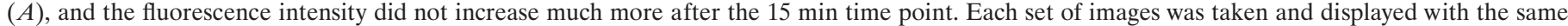
exposure and display conditions in $A$ and $B$. A confocal laser scanning unit was used in $A$ but was not used in $B$. Scale bar, $50 \mu$ m.

ics during the pairing stimulation, especially in fine dendritic regions including the spine, remain to be elucidated.

We reported previously that the activation of ryanodine receptors, another type of $\mathrm{Ca}^{2+}$ channel located on intracellular $\mathrm{Ca}^{2+}$ stores, is necessary for the induction of culture-LTD (Kohda et al., 1995). Because ryanodine receptors are also functionally expressed in Purkinje cells (Ellisman et al., 1990; Kuwajima et al., 1992; Llano et al., 1994), they could play a role in the LTD mechanism in slices, simply being triggered by high $\left[\mathrm{Ca}^{2+}\right] \mathrm{i}$ coming through VGCCs independent of InsP3R. Alternatively, they could be functioning in concert with InsP3R; $\mathrm{Ca}^{2+}$ released from InsP3R could stimulate the ryanodine receptor.

The role of InsP3R in culture LTD remains unclear. Although Kasono and Hirano (1995) reported that heparin blocked the induction of culture-LTD, the concentration of heparin in their study $(2.5 \mathrm{mg} / \mathrm{ml})$ was sufficient to inhibit other cellular components, including PKC and cAMP-dependent protein kinase (Herbert and Maffrand, 1991). In addition, Narasimhan and Linden observed that xestospongin $\mathrm{C}$, a potent antagonist of InsP3R (Gafni et al., 1997), did not block culture-LTD, whereas heparin did (Narasimhan and Linden, 1997; K. Narasimhan and D. Linden, personal communication). These data suggest that InsP3R may not be needed in the induction of culture-LTD, whereas it is needed in LTD in slices. In the culture-LTD protocol, $\mathrm{Ca}^{2+}$ influx through VGCCs, and possibly $\mathrm{Ca}^{2+}$ release from the ryanodine-sensitive stores, might be sufficient to induce LTD. However, in the present study in slices, $\mathrm{Ca}^{2+}$ from the InsP3operated intracellular store was also necessary for LTD. Other differences between the culture and slice LTD systems are known (e.g., a requirement for nitric oxide) (for review, see Linden, 1994). Relevant to these experiments are differences in the anatomical and electrical geometry of the dendrites, density and distribution pattern of VGCCs, and properties of InsP3R. The most important difference may be whether the phenomenon occurs at a synapse. LTD in slices takes place at real PF-Purkinje cell synapses, whereas in culture-LTD, PF stimulation is replaced by artificial glutamate application. Our results in slices may be more relevant and imply that InsP3R1 may play an important role in Purkinje cells in vivo.

Hemart et al. (1995) reported that thapsigargin, which inhibits intracellular $\mathrm{Ca}^{2+}$ release by blocking intracellular Ca-ATPases, did not block the induction of LTD in slices. In their LTD induction protocol, $\mathrm{PF}$ stimulation $(1 \mathrm{~Hz})$ was paired with $\mathrm{Ca}$ spike firing evoked by continuous depolarization for $1 \mathrm{~min}$. The discrepancy between their observations and the data presented here may be explained by differences in experimental conditions. During their pairing protocol, continuous $\mathrm{Ca}$ spike firing might keep $\left[\mathrm{Ca}^{2+}\right] \mathrm{i}$ at a higher level than the protocols used in this study. Periodic depolarizations for $200 \mathrm{msec}$ at $1 \mathrm{~Hz}$ (Fig. 1; in experiments using mutant mice) would cause less $\mathrm{Ca}^{2+}$ influx 

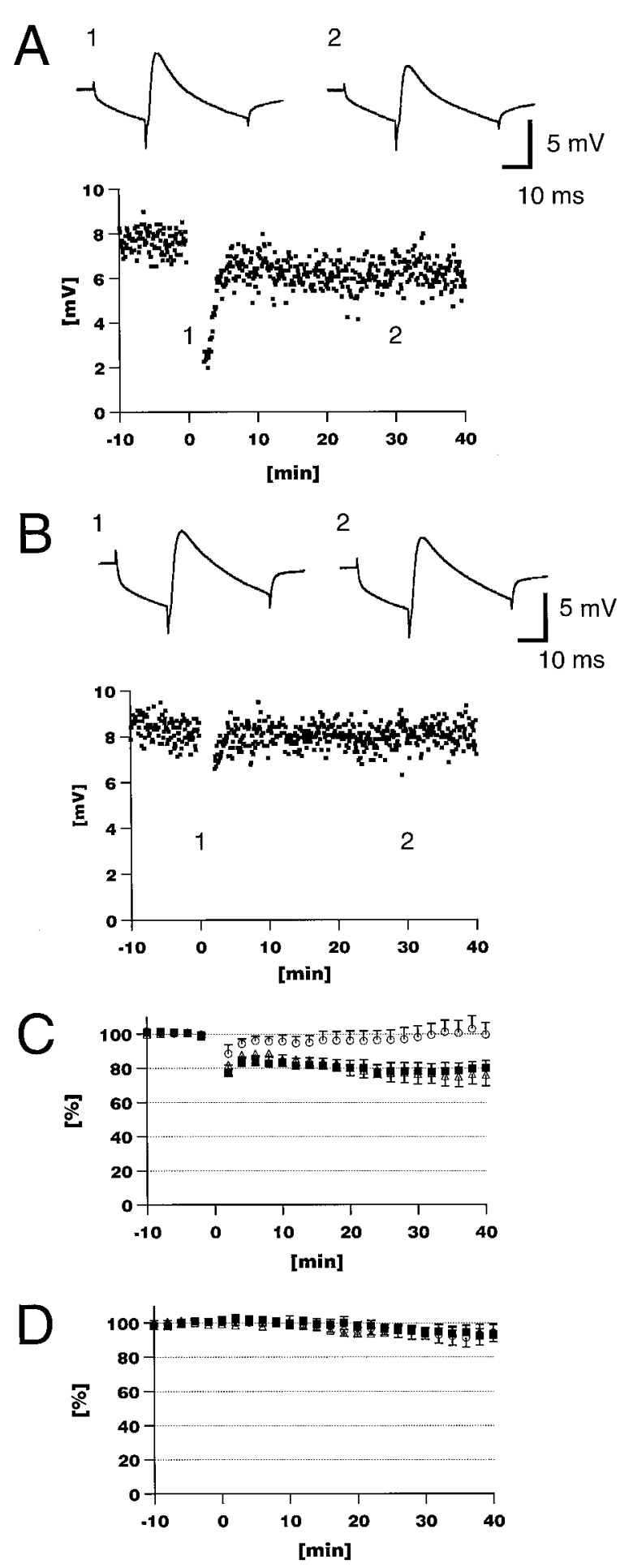

Figure 5. An InsP3R1-specific monoclonal antibody blocked induction of LTD. $A$, Paired CF and PF stimulation $(4 \mathrm{~Hz}, 480$ times) induced long-lasting depression of the PF-EPSP amplitude in a control experiment in which nonspecific rat IgG was included in the patch pipette (160 $\mu \mathrm{g} / \mathrm{ml}) . B, \mathrm{mAb} 18 \mathrm{~A} 10$ blocked the induction of LTD. In insets, the averages of 10 consecutive sweeps obtained at time points indicated are shown. $C$, The averaged time course of the normalized EPSP amplitude, indicating that $\mathrm{mAb} 18 \mathrm{~A} 10(160 \mu \mathrm{g} / \mathrm{ml})$ blocked induction of LTD $(\bigcirc)$, whereas LTD was induced in the presence of nonspecific rat IgG (160 $\mu \mathrm{g} / \mathrm{ml} ; \square)$ and without $\operatorname{IgG}(\triangle) . D$, Without the pairing protocol, the EPSP was stable with mAb18A10 $(160 \mu \mathrm{g} / \mathrm{ml} ; \bigcirc ; n=8$ from 5 animals $)$ and nonspecific rat IgG $(160 \mu \mathrm{g} / \mathrm{ml} ; \mathbf{\square} ; n=5$ from 4 animals $)$ as well as without $\operatorname{IgG}(\triangle ; n=9$ from 9 animals $)$. than the continuous depolarization protocol. In addition, as described previously, the less frequent occurrence of $\mathrm{Ca}$ spikes in young mouse Purkinje cells might lead to less $\mathrm{Ca}^{2+}$ influx than continuous $\mathrm{Ca}$ spike firing. $\mathrm{CF}$ stimuli at $4 \mathrm{~Hz}$ (Fig. 5; in experiments using antibodies) would also load less $\mathrm{Ca}^{2+}$ than the $\mathrm{Ca}$ spike-firing protocol, because the frequency of $\mathrm{Ca}$ spike firing induced by current injection (range, 6-15 Hz) (Llinas and Sugimori, 1980; Lev-Ram et al., 1992) (Inoue and Mikoshiba, unpublished observations) is considerably higher. A single CF stimulus would cause a $\left[\mathrm{Ca}^{2+}\right] \mathrm{i}$ increase similar to that of a single Ca spike (Lev-Ram et al., 1992). Thus, the $\mathrm{Ca}^{2+}$ released by InsP3R1, which was required in this study, could be supplemented by such a high level of $\left[\mathrm{Ca}^{2+}\right)$ i. The induction conditions for LTD used in the present study appear to be less artificial than the conditions that Hemart et al. (1995) adopted, because continuous Ca spike bursting for $1 \mathrm{~min}$ is unlikely to occur in vivo (Armstrong and Rawson, 1979).

In conclusion, our findings clearly demonstrate that intracellular $\mathrm{Ca}^{2+}$ release through the InsP3R1 channel plays an essential role in the induction of LTD in Purkinje cells in slices.

\section{REFERENCES}

Aiba A, Kano M, Chen C, Stanton ME, Gregory DF, Herrup K, Zwingman TA, Tonegawa S (1994) Deficient cerebellar long-term depression and impaired motor learning in mGluR1 mutant mice. Cell 79:377-388

Allbritton NL, Meyer T, Stryer L (1992) Range of messenger action of calcium ion and inositol 1,4,5-trisphosphate. Science 258:1812-1815.

Armstrong DM, Rawson JA (1979) Activity patterns of cerebellar cortical neurones and climbing fibre afferents in the awake cat. J Physiol (Lond) 289:425-448.

Berridge MJ (1993) Inositol trisphosphate and calcium signalling. Nature 361:315-325.

Bezprozvanny I, Watras J, Ehrlich BE (1991) Bell-shaped calciumresponse curves of Ins $(1,4,5) \mathrm{P}_{3^{-}}$and calcium-gated channels from endoplasmic reticulum of cerebellum. Nature 351:751-754.

Chen C, Kano M, Abeliovich A, Chen L, Bao S, Kim JJ, Hashimoto K, Thompson RF, Tonegawa S (1995) Impaired motor coordination correlates with persistent multiple climbing fiber innervation in $\mathrm{PKC} \gamma$ mutant mice. Cell 83:1233-1242.

Conquet F, Bashir ZI, Davies CH, Daniel H, Ferraguti F, Bordi F, Franz-Bacon K, Reggiani A, Matarese V, Conde F, Collingridge GL, Crepel F (1994) Motor deficit and impairment of synaptic plasticity in mice lacking mGluR1. Nature 372:237-243.

Crepel F, Jaillard D (1991) Pairing of pre- and postsynaptic activities in cerebellar Purkinje cells induces long-term changes in synaptic efficacy in vitro. J Physiol (Lond) 432:123-141.

Crepel F, Krupa M (1988) Activation of protein kinase C induces a long-term depression of glutamate sensitivity of cerebellar Purkinje cells. An in vitro study. Brain Res 458:397-401.

Ellisman MH, Deerinck TJ, Ouyang Y, Beck CF, Tanksley SJ, Walton PD, Airey JA, Sutko JL (1990) Identification and localization of ryanodine binding proteins in the avian central nervous system. Neuron 5:135-146.

Furuichi T, Yoshikawa S, Miyawaki A, Wada K, Maeda N, Mikoshiba K (1989) Primary structure and functional expression of the inositol 1,4,5-trisphosphate-binding protein $\mathrm{P}_{400}$. Nature 342:32-38.

Furuichi T, Simon-Chazottes D, Fujino I, Yamada N, Hasegawa M, Miyawaki A, Yoshikawa S, Guenet J-L, Mikoshiba K (1993) Widespread expression of inositol 1,4,5-trisphosphate receptor type 1 gene (Insp3r1) in the mouse central nervous system. Receptors Channels 1:11-24.

Gafni J, Munsch JA, Lam TH, Catlin MC, Costa LG, Molinski TF, Pessah IN (1997) Xestospongins: potent membrane permeable blockers of the inositol 1,4,5-trisphosphate receptor. Neuron 19:723-733.

Hamada E, Nakajima T, Ota S, Terano A, Omata M, Nakade S, Mikoshiba K, Kurachi Y (1993) Activation of $\mathrm{Ca}^{2+}$-dependent $\mathrm{K}^{+}$current by acetylcholine and histamine in a human gastric epithelial cell line. J Gen Physiol 102:667-692. 
Hartell NA (1994a) cGMP acts within cerebellar Purkinje cells to produce long term depression via mechanisms involving PKC and PKG. NeuroReport 5:833-836.

Hartell NA (1994b) Induction of cerebellar long-term depression requires activation of glutamate metabotropic receptors. NeuroReport 5:913-916

Hemart N, Daniel H, Jaillard D, Crepel F (1995) Receptors and second messengers involved in long-term depression in rat cerebellar slices in vitro: a reappraisal. Eur J Neurosci 7:45-53.

Herbert J-M, Maffrand J-P (1991) Effect of pentosan polysulphate, standard heparin and related compounds on protein kinase C activity. Biochim Biophys Acta 1091:432-441.

Inoue T, Mikoshiba K (1997) Type 1 inositol 1,4,5-trisphosphate receptor is essential in long-term depression in cerebellar Purkinje neuron. Soc Neurosci Abstr 23:1965.

Ito M (1989) Long-term depression. Annu Rev Neurosci 12:85-102.

Kasai H, Petersen OH (1994) Spatial dynamics of second messengers: IP3 and cAMP as long-range and associative messengers. Trends Neurosci 17:95-101.

Kasono K, Hirano T (1995) Involvement of inositol trisphosphate in cerebellar long-term depression. NeuroReport 6:569-572.

Kohda K, Inoue T, Mikoshiba K (1995) $\mathrm{Ca}^{2+}$ release from $\mathrm{Ca}^{2+}$ stores, particularly from ryanodine-sensitive $\mathrm{Ca}^{2+}$ stores, is required for the induction of LTD in cultured cerebellar Purkinje cells. J Neurophysiol $74: 2184-2188$.

Khodakhah K, Armstrong C (1997) Induction of long-term depression and rebound potentiation by inositol trisphosphate in cerebellar Purkinje neurons. Proc Natl Acad Sci USA 94:14009-14014.

Khodakhah K, Ogden D (1993) Functional heterogeneity of calcium release by inositol trisphosphate in single Purkinje neurones, cultured cerebellar astrocytes, and peripheral tissues. Proc Natl Acad Sci USA 90:4976-4980.

Khodakhah K, Ogden D (1995) Fast activation and inactivation of inositol trisphosphate-evoked $\mathrm{Ca}^{2+}$ release in rat cerebellar Purkinje neurones. J Physiol (Lond) 487:343-358.

Konnerth A, Dreessen J, Augustine GJ (1992) Brief dendritic calcium signals initiate long-lasting synaptic depression in cerebellar Purkinje cells. Proc Natl Acad Sci USA 89:7051-7055.

Kuwajima G, Futatsugi A, Niinobe M, Nakanishi S, Mikoshiba K (1992) Two types of ryanodine receptors in mouse brain: skeletal muscle type exclusively in Purkinje cells and cardiac muscle type in various neuron. Neuron 9:1133-1142.

Lev-Ram V, Miyakawa H, Lasser-Ross N, Ross WN (1992) Calcium transients in cerebellar Purkinje neurons evoked by intracellular stimulation. J Neurophysiol 68:1167-1177.

Linden DJ (1994) Long-term synaptic depression in the mammalian brain. Neuron 12:457-472.

Linden DJ, Connor JA (1991) Participation of postsynaptic PKC in cerebellar long-term depression in culture. Science 254:1656-1659.

Llano I, Dreessen J, Kano M, Konnerth A (1991) Intradendritic release of calcium induced by glutamate in cerebellar Purkinje cells. Neuron 7:577-583.

Llano I, DiPolo R, Marty A (1994) Calcium-induced calcium release in cerebellar Purkinje cells. Neuron 12:663-673.

Llinas R, Sugimori M (1980) Electrophysiological properties of in vitro Purkinje cell somata in mammalian cerebellar slices. J Physiol (Lond) 305:171-195.

Matsumoto M, Nakagawa T, Inoue T, Nagata E, Tanaka K, Takano H, Minowa O, Kuno J, Sakakibara S, Yamada M, Yoneshima H, Miyawaki A, Fukuuchi Y, Furuichi T, Okano H, Mikoshiba K, Noda T (1996) Ataxia and epileptic seizures in mice lacking type 1 inositol 1,4,5trisphosphate receptor. Nature 379:168-171.

Miyakawa H, Lev-Ram V, Lasser-Ross N, Ross WN (1992) Calcium transients evoked by climbing fiber and parallel fiber synaptic inputs in guinea pig cerebellar Purkinje neurons. J Neurophysiol 68:1178-1189.

Miyazaki S, Yuzaki M, Nakada K, Shirakawa H, Nakanishi S, Nakade S, Mikoshiba K (1992) Block of $\mathrm{Ca}^{2+}$ wave and $\mathrm{Ca}^{2+}$ oscillation by antibody to the inositol 1,4,5-trisphosphate receptor in fertilized hamster eggs. Science 257:251-255.

Nakade S, Maeda N, Mikoshiba K (1991) Involvement of the C-terminus of the inositol 1,4,5-trisphosphate receptor in $\mathrm{Ca}^{2+}$ release analyzed using region-specific monoclonal antibodies. Biochem J 277:125-131.

Narasimhan K, Linden DJ (1997) A test of the calcium threshold hypothesis for cerebellar LTD induction. Soc Neurosci Abstr 23:1178.

Sakurai M (1990) Calcium is an intracellular mediator of the climbing fiber in induction of cerebellar long-term depression. Proc Natl Acad Sci USA 87:3383-3385.

Shigemoto R, Abe T, Nomura S, Nakanishi S, Hirano T (1994) Antibodies inactivating mGluR1 metabotropic glutamate receptor block longterm depression in cultured Purkinje cells. Neuron 12:1245-1255.

Tank DW, Sugimori M, Connor JA, Llinas RR (1988) Spatially resolved calcium dynamics of mammalian Purkinje cells in cerebellar slice. Science 242:773-777.

Vranesic I, Batchelor A, Gahwiler BH, Garthwaite J, Staub C, Knopfel T (1991) Trans-ACPD-induced $\mathrm{Ca}^{2+}$ signals in cerebellar Purkinje cells. NeuroReport 2:759-762. 